\title{
Insulin like growth factor and risk of breast cancer
}

\author{
Athar Hasssan Abd ullah, Kismat Mohammed Turki, Manwar A. AL Naqqash \\ M.Sc. Clinical Biochemistry \\ Ph.D. Clinical Biochemistry \\ D.M.R.T. Clinical Oncology, M.Sc. Pathology
}

\begin{abstract}
Summary
Background :-Breast cancer is responsible for the death of millions of women worldwide every year. It is widespread in the world and Iraq that become a genuine problem for public health. The etiology of the disease is unknown. Genetic and hormonal factors are involved in the development of breast cancer and progression of the disease. Insulin like growth factor-l (IGF-l) have been implicated as essential in controlling cellular differentiation and tissue regeneration, through mitogenic, anti-apoptotic and increases cell migration so IGF-lpromotetumorigenesis.

Objective:- To evaluate the role of $I G F-l$, insulin, estrogen and lipid profile in patients with breast cancer and their contribution to the pathogenesis of breast cancer.

Subjects and Methods :- This study included 60 patients with primary breast cancer age range (29-70) years and 60 age matched healthy controls. The subjects were selected from patients attending the Clinic Medical City/Baghdad Teaching Hospital / Oncology unit. Insulin like growth factor-I, insulin and estrogen were measured by ELISA.

Results:- Serum insulin like growth factor-I and insulin in breast cancer patients were significantly higher than healthy controls $(p<0.01)$. The level of IGF-l and estrogen are significantly higher in serum of premenopausal patients than the other studied groups $(p<0.01)$. There were significantdifferences in cholesterol and low density lipoprotein $(L D L)(p<0.01)$, while there was no significant difference in the level of high density lipoprotein (HDL) between premenopausal patients and control $(P>0.05)$, but there was a significant difference between postmenopausal patients and control group $(P<0.01)$.

Conclusion :- Insulin like growth factor-l and estrogen level increased in the breast cancer in premenopausal patients, these results suggested that levels of serum IGF-I and estrogen together can be used as a predictive markers for breast cancer in the premenopausal women.

Key word:- Insulin like growth factor - $l$, Insulin, Estrogen, Breast cancer
\end{abstract}

\section{Introduction:-}

Breast Cancer is widespread that it has become a genuine problem for public health, with about one woman in ten developing it in her lifetime throughout the world. Its incidence increases with age, being uncommon below the age of 30, and its behavior varies from a slowly progressive to a rapidly progressive disease despite all forms of treatment (1). Genetic and hormonal factors that are involved in the development of breast cancer and progression of the disease. Several genetic alterations have been associated with an increased risk of breast cancer development. Mutations in two breast cancer susceptibility genes, BRCA 1 and 2 have been shown to predispose women to breast cancer, however mutations in these genes account for only $5 \%$ of breast cancer cases. The factors responsible for the remaining $95 \%$ are still obscure. Breast cancer primarily affects women, however, it occasionally affects men. The female to male ratio of breast cancer prevalence is 100:1 Breast cancer accounts for $0.2 \%$ of all cancer cases in men (2). Other factors known to be involved in breast cancer development are hormones and growth factors. The finding that breast cancer is rare in males as well as in nonestrogenized women suggests that most, if not all, breast cancers originate as a hormone-dependent disease(3). Insulin like growth factor-I (IGFI) are multifunctional peptides that regulate cell proliferation differentiation and apoptosis attributes important in tumorigenesis (4). (IGFI) is a potent mitogen for both normal and transformed breast epithelial cells and serum IGF-I level is associated with the development of mammary gland hyperplasia and cancer in a primate model, increased expression of insulin like growth factor- I receptor (IGF I R) in the cytoplasm of the benign ductal epithelium is correlated with the risk of breast carcinoma development. Estrogens are critical for the development and normal physiological function of female reproductive tissues including the mammary gland (5). About two-third of breast carcinomas have an estrogen receptor positive status, but $50 \%$ of patients respond to anti-estrogen treatment $(6)$. Therefore, oestrogen is believed to increase the risk of breast cancer(7). Insulin promotes the production and activity of (IGF- I) (8), which can promote cell proliferation in an over-nutrition state. The metabolic ramifications of chronic hyperinsulinemia are diverse and complex. It has been demonstrated that the compensatory hyperinsulinemia that characterizes adolescent obesity chronically suppresses hepatic synthesis of insulin like growth factor binding protein- I (IGFBP- I) which in turn 
serves to increase free insulin like growth factor- I (9), the biologically active part of circulating IGF- I. The increase in circulating levels of insulin and IGFBP- I vary inversely throughout the day, and the suppression of IGFBP-1 by insulin, and hence elevation of free IGF- I (10).

\section{Subjects and methods: -}

This study was performed during the period from November 2011 to March 2012, included 60 patients with primary breast cancer (30 premenopausal +30 postmenopausal ) attending Baghdad Teaching Hospital Oncology unit. Exclusion criteria was patient with diabetes mellitus or History of ovary or uterus cancer?, and 60 healthy individuals ( 30 premenopausal +30 postmenopausal ), as control group . Five ml venous blood aspired from each patient and control, samples were collected after 10 hours fasting. Levels of insulin like growth factor-I (IGF-I), insulin and estrogen were measured using ELISA technique.

\section{Statistical Analysis:-}

Social process statistical system (SPSS ) was used to compare the significance of the difference in the mean values at any two patients and control.

Student t-test was applied, the comparison of p-value significance (sig) In any test:

$\mathrm{S}=$ Significant difference $(\mathrm{p}<0.05)$

HS=Highly Significant difference $(p<0.01), N S=$ Non Significant difference $(p>0.05)$

The correlation coefficient (r) test is used to describe the association between different parameter studied.

\section{Results :-}

The concentration of insulin like growth factor -1 (IGF-1) and estrogen in serum of premenopausal breast cancer patients were significantly higher than in serum of premenopausal control group $(\mathrm{P}<0.01)$ Table $(1-1)$. And there was significant elevation $(p<0.01)$ in the level of IGF-I in serum of the premenopausal patients compared with other groups in the study as shown in Figure (1-1). There was a significant elevation ( $\mathrm{p}<$ 0.01 ) in the level of insulin in serum of the premenopausal patients compared with premenopausal control group. But there was no significant difference in the level of serum insulin between postmenopausal patients and control $(\mathrm{p}=0.669)$. And There were significant differences in cholesterol and low density lipoprotein (LDL) $(p<0.01)$.The level of Triglyceride in serum of premenopausal patients was significantly higher than its level in serum of premenopausal control group $(\mathrm{P}<0.01)$, but there was no significant difference in the level of (TG)in serum of postmenopausal patients compared with postmenopausal control group $(\mathrm{P}=0.565)$, while there is no significant difference in the level of high density lipoprotein (HDL) between premenopausal patients and control $(\mathrm{P}=0.133)$, but there was a significant difference between postmenopausal patients and control groups $(\mathrm{P}=0.015)$ Table (1-2).

Table (1-1) Mean \pm SD of serum Insulin like growth factor -l, serum Estrogen and Age of Breast cancer patients and control groups

\begin{tabular}{|c|c|c|c|c|c|c|}
\hline \multirow[b]{2}{*}{ Parameters } & \multicolumn{4}{|c|}{ studied groups } & \multirow[b]{2}{*}{ p-value } & \multirow[b]{2}{*}{ sig } \\
\hline & $\begin{array}{c}\text { PRE.MP } \\
\text { Mean } \pm \text { SD } \\
n=30\end{array}$ & $\begin{array}{c}\text { PRE.MC } \\
\text { Mean } \pm \text { SD } \\
\mathbf{n}=\mathbf{3 0}\end{array}$ & $\begin{array}{c}\text { POS.MP } \\
\text { Mean } \pm \text { SD } \\
\mathbf{n}=\mathbf{3 0}\end{array}$ & $\begin{array}{c}\text { POS.MC } \\
\text { Mean } \pm \text { SD } \\
\mathbf{n}=\mathbf{3 0}\end{array}$ & & \\
\hline $\begin{array}{l}\text { Insulin like growth factor- } \\
\qquad \mathrm{l}(\mathrm{ng} / \mathrm{ml})\end{array}$ & $\begin{array}{c}431.033 \pm 83 \\
.080\end{array}$ & $\begin{array}{l}287.500 \\
\pm 62.868\end{array}$ & $\begin{array}{l}306.100 \\
\pm 82.972\end{array}$ & $\begin{array}{l}259.066 \\
\pm 61.204\end{array}$ & $<0.01$ & HS \\
\hline Estrogen(pg/ml) & $\begin{array}{c}147.433 \pm 57 \\
.936\end{array}$ & $\begin{array}{c}66.033 \\
\pm 19.373\end{array}$ & $\begin{array}{c}\mathbf{2 6 . 2 0 0} \\
\pm 18.355\end{array}$ & $\begin{array}{l}32.333 \\
\pm 20.255\end{array}$ & $<0.01$ & HS \\
\hline Age (year) & $\begin{array}{l}40.366 \\
\pm 4.205 \\
\end{array}$ & $\begin{array}{l}31.133 \\
\pm 6.240 \\
\end{array}$ & $\begin{array}{l}59.033 \\
\pm 6.172 \\
\end{array}$ & \begin{tabular}{|l|}
52.433 \\
\pm 1.851 \\
\end{tabular} & $<0.01$ & HS \\
\hline
\end{tabular}

HS=Highly Significant

Table (1-2) (Mean \pm SD) of lipid profile in serum of the studied groups

\begin{tabular}{|c|c|c|c|c|c|c|}
\hline \multirow[b]{2}{*}{ Parameters } & \multicolumn{6}{|c|}{ studied groups } \\
\hline & $\begin{array}{c}\text { PRE.MP } \\
\text { Mean } \pm \text { SD } \\
\mathbf{n}=\mathbf{3 0}\end{array}$ & $\begin{array}{c}\text { PRE.MC } \\
\text { Mean } \pm \text { SD } \\
\mathbf{n}=\mathbf{3 0}\end{array}$ & p-value & $\begin{array}{c}\text { POS.MP } \\
\text { Mean } \pm \text { SD } \\
\mathbf{n}=\mathbf{3 0}\end{array}$ & $\begin{array}{c}\text { POS.MC } \\
\text { Mean } \pm \text { SD } \\
\mathbf{n}=\mathbf{3 0}\end{array}$ & p-value \\
\hline $\begin{array}{l}\text { Cholesterol } \\
\text { (mg/dl) }\end{array}$ & $\begin{array}{l}201.800 \\
\pm 40.090\end{array}$ & $\begin{array}{l}151.200 \\
\pm 18.501\end{array}$ & $\begin{array}{c}<0.01 \\
\text { HS }\end{array}$ & $\begin{array}{l}201.900 \\
\pm 43.036\end{array}$ & $\begin{array}{l}165.933 \\
\pm 33.301\end{array}$ & $\begin{array}{c}<0.01 \\
\text { HS }\end{array}$ \\
\hline $\begin{array}{c}\text { Triglyceride } \\
\text { (mg/dl) }\end{array}$ & $\begin{array}{l}\mathbf{1 7 9 . 0 6 6} \\
\pm 87.558\end{array}$ & $\begin{array}{l}103.466 \\
\pm 50.020\end{array}$ & $\begin{array}{c}<0.01 \\
\text { HS }\end{array}$ & $\begin{array}{l}143.400 \\
\pm 72.100\end{array}$ & $\begin{array}{l}154.566 \\
\pm 84.041\end{array}$ & $\begin{array}{l}0.565 \\
\text { NS }\end{array}$ \\
\hline
\end{tabular}




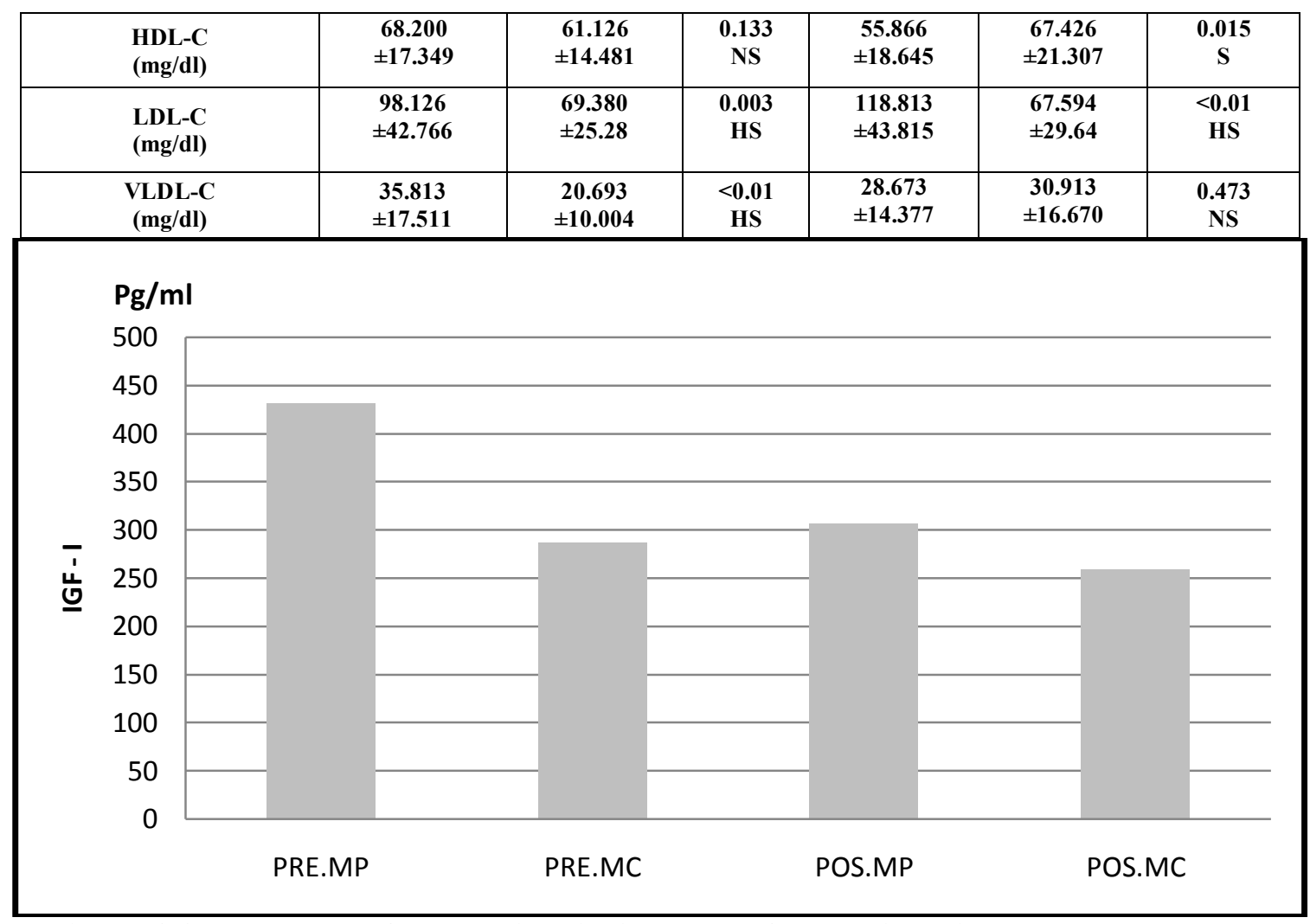

Figure (1-1) Mean value for serum insulin like growth factor -I in patients and control group

\section{Discussion :-}

There are several cellular actions of insulin like growth factor -1 (IGF-1). It has the nature to stimulate multiple cellular responses that are related to growth such as synthesis of DNA, RNA, and cellular proteins; and inducing metastasis in many types of malignancies. The IGF-l signaling also interplays with estrogen activity on many levels in the development and progression of breast cancer (11). The differences in IGF-I levels associated with menopausal status; IGF-I is different for pre and post-menopausal breast cancer. Premenopausal women had consistently higher IGF-I levels than postmenopausal women. Such results may reflect the differential effects of IGF-1 on cell growth between pre- and post-menopausal breast tissues (12). And/or the complex inter-relationships between breast connective tissue, fat and epithelium with increasing age (13). The relative concentration of estrogen and IGF-l might be related to risk in premenopausal women in whom oestradiol enhance the action of IGF-I in breast cells, as indicated by the significant positive correlation between IGF-I and estrogen found in this study. Whereas in the postmenopausal setting, both hormones exist at sub-threshold concentration, thereby incapable of affecting tumorigenesis (14). Oestrogens have a proliferative effect on breast tissue, are probably related to increase mitotic activity, and are believed to be a promoting influence rather than an initiating effect. The proliferation of cells is essential for carcinogenesis because the risk of errors during deoxyribonucleic acid replication is increased during cell division, which if not corrected, can lead to cancer (15). Alteration in hormone levels are to influence breast carcinogenesis through several mechanisms .One thus exposure to higher estrogen levels, is the principal factor contributing to the risk of breast cancer (16). Estrogen exposure may contribute to carcinogenesis by increasing the rate of cell division and proliferation, thereby allowing for an increase in the accumulation of random genetic errors. Another hypothesis is that the continued cell division and proliferation resulting from multiple ovulatory cycles, principally between menarche and first birth, increases the susceptibility of breast tissue to carcinogenic environmental insults the duration of exposure to both endogenous and exogenous estrogen is directly related to the risk of developing breast cancer (17). Insulin may also play a role in breast carcinogenesis via the extensive cross talk that occurs between the insulin - IGF and the estrogen signaling pathways in breast tissue. Insulin and estradiol can act in concert to promote cell cycle progression in breast cancer cells. And insulin activates estrogen receptor alpha - mediated transcription in breast cancer cell lines, even in the absence of estradiol. Whereas estrogen stimulates the insulin signaling pathway by enhancing mitogen-activated protein kinase (MAPK) activation ( 18 ). Insulin may signal cells to proliferate through a variety of mechanisms either directly or indirectly by increasing the levels and bioactivity of other more potent growth factors, such as IGF-I. Insulin is able to decrease insulin like growth factor binding 
protein system (IGFBPs), such as insulin like growth factor binding protein-1 (IGFBP-1) (which is coordinately regulated with sex hormone binding protein) with a consequent increase in IGF bioactivity, or it can make cells more sensitive to other growth factors, such as estradiol. Insulin also regulates the levels of growth hormone receptors on hepatocytes, which are the main source of circulating IGF-I and hence may also act indirectly via increasing IGF-1 production (19). The relationship between lipids and breast cancer is obscure . Lipids might primarily affect the gonads .The high concentration of triglycerides may lead a decreased level of sex hormonebinding globulin, resulting in higher amount of free estradiol, (20).

\section{References}

[1]. W.K.B.A. Owiredu, S. Donkor, B. Wiafe Addai and N. Amidu” Serum Lipid Profile of Breast Cancer Patients". Pakistan Journal of Biological Sciences, 2009. 12: 332-338

[2]. Khandwala HM, McCutcheon IE, Flyvbjerg A, Friend KE. "The effects of insulin-like growth factors on tumorigenesis and neoplastic Growth" Endocr Rev 2000; 21: 215-44

[3]. MacMahon B, Cole P, Lin TM, Lowe CR, Mirra AP, Ravnihar B, Salber EJ, Valaoras VG \&Yuasa S Age at first birth and breast cancer risk. Bulletin of the World Health Organization1970,43209-221.5.

[4]. Polednak, A.P., Epidemiology of breast cancer in Connecticut women. Conn Med. 1999., 63: 7-16.

[5]. Ma, Z. Q., Santagati, S., Patrone, C., Pollio, G., Vegeto, E., and Maggi, A. (1994) Mol. Endocrinol. 8, $910-918$.

[6]. Pamplona DC, de Abreu Alvim C. Breast Reconstruction with Expanders and Implants: a Numerical Analysis. Artificial Organs (2004), 8, pp. 353-356

[7]. Hollander, Anne Seeing through Clothes. University of California Press, Berkeley. 1993 ,ISBN 978-0-520-08231-1

[8]. ttia N, Tamborlane WV, Heptulla R, et al. The metabolic syndrome and insulinlike growth factor I regulation in adolescent obesity. J Clin Endocrinol Metab1998;83:1467-71.

[9]. Brismar K, Fernqvist-Forbes E, Wahren J, et al. Effect of insulin on the hepatic production of insulin-like growth factor-binding protein-1 (IGFBP-1), IGFBP-3, and IGF-1 in insulin dependent diabetes. J Clin Endocrinol Metab 1994;79:872- 78.

[10]. Holly JMP. The physiological role of IGFBP-1. Acta Endocrinol 1991;124:55-62

[11]. Qiu-Li Zhu 1, Wang-Hong Xu 1,* and Meng-Hua Tao 2,* Biomarkers of the Metabolic Syndrome and Breast Cancer Prognosis,, Cancers 2010, 2, 721-739

[12]. Renehan AG, Jones J, O’Dwyer ST, Shalet SM. Determination of IGF-I, IGF-II, IGFBP-2, and IGFBP-3 levels in serum and plasma: comparisons using the Bland- Altman method. Growth Horm IGF Res2003; 13: 341-46

[13]. Howell A, Sims AH, Ong KR, Harvie MN, Evans DG \& Clarke RB Mechanisms of disease: prediction and prevention of breast cancer - cellular and molecular interactions. Nature Clinical Practice Oncology,2005,2635_646

[14]. Ruan W, Catanese V, Wieczorek R, et al. Estradiol enhances the stimulatory effect of insulin-like growth factor-I (IGF-I) on mammary development and growth hormone-induced IGF-I messenger ribonucleic acid. Endocrinology 1995;136:1296-302

[15]. Ho C C K, Rohaizak M, Zulkifli S Z, Siti-Aishah M A, Nor-Aini U, Sharifah-Noor- Akmal S H, Serum sex hormone levels in preand postmenopausal breast cancer patients, Singapore Med J 2009; 50(5) : 513.

[16]. Henderson BE,Ross RK,Pike MC. Hormonal chemoprevention of cancer in women .science, 1993;259:633-638

[17]. Preston-Martin S,Pike MC, Ross RK,et al. Epidemiologic evidence for the increased cell proliferation model of carcinogenesis . prog clin Boil Res 1991;369:21-24

[18]. Riccardo Vigneri, MD,, Insulin, Insulin-like Growth Factor-I, and Risk of Breast Cancer in Postmenopausal Women, Endocrinology Division, Department of Internal and Specialistic Medicine, 2009 Vol,678

[19]. Claire M. Perks, PhD*, Jeff M.P. Holly, PhD Hormonal Mechanisms Underlying the Relationship Between Obesity and Breast Cancer Endocrinol Metab Clin N Am 40 (2011) 485-507.

[20]. Shah FD, Shukla SN, Shah PM, Patel HR, Patel PS. Significance of alterations in plasma lipid profile levels in breast cancer. Integr Cancer Ther 2008; 7: 33-41. 